\title{
Histone H2B Type 1-C/E/F/G/I
}

National Cancer Institute

\section{Source}

National Cancer Institute. Histone H2B Type 1-C/E/F/G/I. NCI Thesaurus. Code C162934.

Histone H2B type 1-C/E/F/G/I (126 aa, 14 kDa) is encoded by the human H2BC4, $\mathrm{H} 2 \mathrm{BC} 6, \mathrm{H} 2 \mathrm{BC} 7, \mathrm{H} 2 \mathrm{BC} 8$ and $\mathrm{H} 2 \mathrm{BC} 10$ gene. This protein is involved in histone-mediated transcription regulation, DNA repair, DNA replication and chromosomal stability. 